\title{
Estimating the Reliability of Sprinkler Systems in Australian High-rise Office Buildings
}

\author{
KHALID MOINUDDIN, IAN THOMAS, and SAMINA CHEA \\ Centre for Environmental Safety and Risk Engineering \\ Victoria University, P.O. Box 14428, Melbourne MC, Victoria 8001, Australia
}

\begin{abstract}
A comprehensive survey of sprinkler systems in high-rise office buildings was carried out to determine the reliability of various components of such systems in Australia. Based on the survey data, a fault tree analysis (FTA) has been used to estimate the overall reliability of these sprinkler systems. Data from twenty three buildings were collected and are presented in this paper. The analyses are confined only to wet-pipe systems, as these constitute the vast majority of automatic sprinkler systems in Australia and New Zealand. A range of reliability for the sprinkler systems is estimated based on number of considerations. Sprinkler zone shut off during tenancy changes and sprinkler head failure appear to be the main factors that may lead to a sprinkler system failure.
\end{abstract}

KEYWORDS: sprinkler, reliability, effectiveness, survey, tenancy change, failure rate, probability

\section{NOMENCLATURE LISTING}

$\mathrm{P} \quad$ failure rate per demand

Greek

$\mathrm{P}(\mathrm{V})$

failure rate of zone isolation valve

$\lambda$

failure rate per unit time

per demand

$\sigma \quad$ standard deviation of the data

$n \quad$ number of buildings

$\mu \quad$ mean value of the data

\section{INTRODUCTION}

Water is supplied to automatic fire sprinklers (or sprinkler heads) through a system of piping, and the sprinkler heads are arranged so that they are able to automatically distribute sufficient water directly to a fire to extinguish it or hold it in check until fire fighters arrive [1]. This is achieved by cooling the fire and wetting surrounding materials in order to make them harder to ignite.

The effectiveness of a fire-safety system can be considered as the product of its efficacy and its reliability [2]. The reliability of a sprinkler system is defined as the likelihood that it operates when required (this was reported as nearly $91.5 \%$ by both Kim [3] from US statistics of high-rise building fires in 1988 and Rohr and Hall [4] from US statistics of store and office fires in 1999-2002) and delivers the designed amount of water to the fire. In this paper, the analyses are confined to wet-pipe systems as these are the vast majority of automatic sprinkler systems in Australia and New Zealand. Wet-pipe systems are installations in which the sprinkler piping network is permanently charged with water under pressure and are therefore suitable for use in buildings in which freezing never occurs [5]. The purpose of the fault tree analysis in this paper is to estimate the reliability of sprinkler systems in high-rise office buildings in Australia.

\section{DESCRIPTION OF AUTOMATIC SPRINKLER SYSTEM IN A TYPICAL HIGH RISE BUILDING}

A detailed description of the sprinkler system in high-rise office building is given in [6]. A short description is presented in this paper for the purpose of clarity. Figure 1 shows a legend of symbols for various components of a sprinkler system while Fig. 2 presents a schematic diagram of a typical sprinkler system for a 60 storey building.

As shown in Fig. 2 three tappings are taken from each water main to transfer water for normal supply, sprinklers and fire hydrant/hoses. It is shown by detailed calculation in [6] that for sprinklers, town mains pressure is only sufficient to supply water to the sprinkler system for few lower storeys (usually up to eight storeys). To supply water above the lowest eight storeys, water pressure is required to be boosted by a set of pumps. Therefore for sprinklers, water is drawn from town mains and either supplied directly to the pump or is stored in basement reservoirs/tanks and then is pumped to the riser (vertical pipes). Water flows 
through non-return valves, pump isolation valves, pumps, the main sprinkler valve and then alarm valves to the riser. When water flows through the alarm valve, an alarm sounds to the fire brigade and to the building.

\begin{tabular}{|c|c|}
\hline Symbol & Meaning \\
\hline$\rightarrow \infty$ & Stop vdve - normally open \\
\hline$\rightarrow-$ & Stop valve-normally closed \\
\hline$\frac{1}{1}$ & Pressure reducing valve \\
\hline$\phi$ & Alarm valve \\
\hline$-1+$ & $\begin{array}{c}\text { Non-re tum valve } \\
\text { (direction of tow }- \text { ) }\end{array}$ \\
\hline
\end{tabular}

\begin{tabular}{c|c}
\hline Symbol & Meaning \\
\hline$\square$ & Sprinkler he ad \\
\hline & Float vdve \\
\hline & \\
\hline
\end{tabular}

Fig. 1. Legend of symbols

Both single-stage or multi-stage pumps are permitted for use in Australian buildings. Normally, one electrical and one diesel pump is used. Single-stage pumps deliver water at a single pressure only, multistage pumps deliver water at different pressures suitable for different levels in the building. Separate pressure switches are required to activate each pump.

A pump bypass system is usually provided to supply water under mains pressure to the lower storeys (usually a maximum of eight) in the building, as a back-up supply. [6] also shows that in Australian high rise buildings in excess of $75 \mathrm{~m}$ (approximately 21 storeys), the sprinkler system needs to be divided into stages each of consists of $\leq \sim 20$ storeys. It is also important to mention that a typical riser usually supplies water to a floor area of up to $9000 \mathrm{~m}^{2}$ [7] (usually seven or eight floors). Thus seven or eight floors comprises a zone. Thereby, each stage is divided into three zones; in each zone water is supplied by a separate riser. These risers are controlled by separate stop valves. At the interface of the stages, usually a plant room is located where multiple risers emanate from the main riser (manifold type; see Fig. 3) to supply water to the respective sprinkler zones within the stage.

The building is usually supplied with water in one of two primary ways:

- Upfeed system- by pump pressure only (Fig. 2)

- Downfeed system- by gravity (the schematic diagram of this system is not presented in this paper due to the space constraint, but can be viewed in [6]).

In the surveyed buildings, multi-stage pumps are primarily used in an upfeed system. A set of very high pressure single-stage pumps are usually used for a downfeed system covering the entire building. In this case single-stage pumps supply water directly to two tanks at the top of the building. The tanks must be placed sufficiently above the roof to provide the required pressure for the sprinkler heads located in the top floor. Alternatively, a small low pressure pump is used to achieve protection for the first few floors at the top of the building. However as discussed previously, to supply water to a floor 20 or more storeys below the gravity tank, water pressure needs to be reduced. In a building with a multiple stages sprinkler system, in the plant room a riser from the upper stage feeds the riser of the lower stage with the help of one of the following options:

- a pair of pressure reducing valves to reduce water pressure for the lower stage

- a pair of cell tanks storing the required amount of water, from which water is supplied for the lower stage

It is a usual practice in the Australian buildings to install cell tanks or pressure reducing valves in pairs to improve the reliability of the system. This requirement is not obvious in the Australian Standard [7].

\section{FAULT TREE CONSTRUCTION}

A number of fault trees have been constructed based on an upfeed system for a 60 storey building shown in Fig. 2 covering various stages. For this system, zones of stages 2 and 3 are the most vulnerable. One of the 


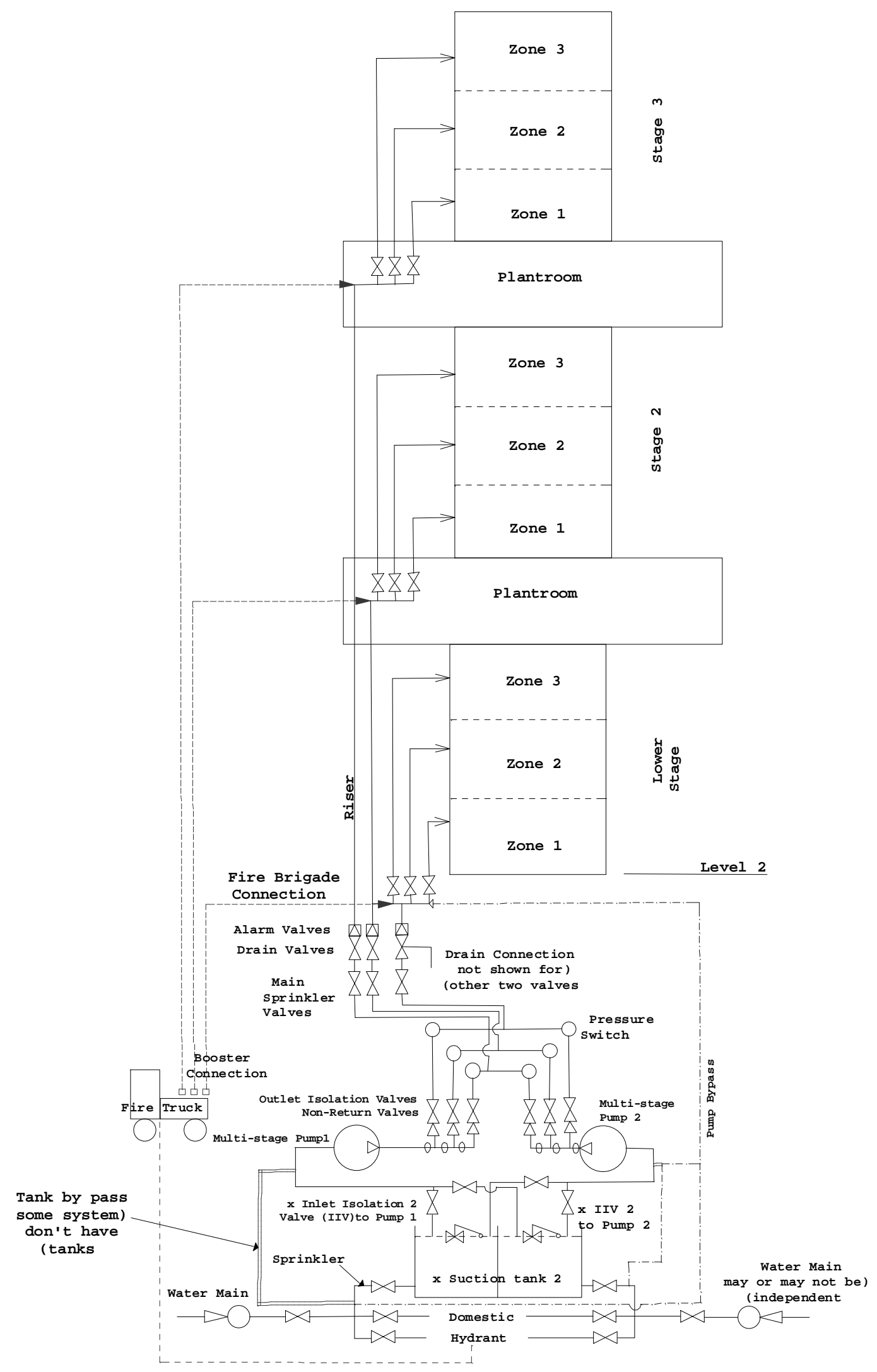

Fig. 2. Details of water supply and upfeed sprinkler system for a 60 storey building 

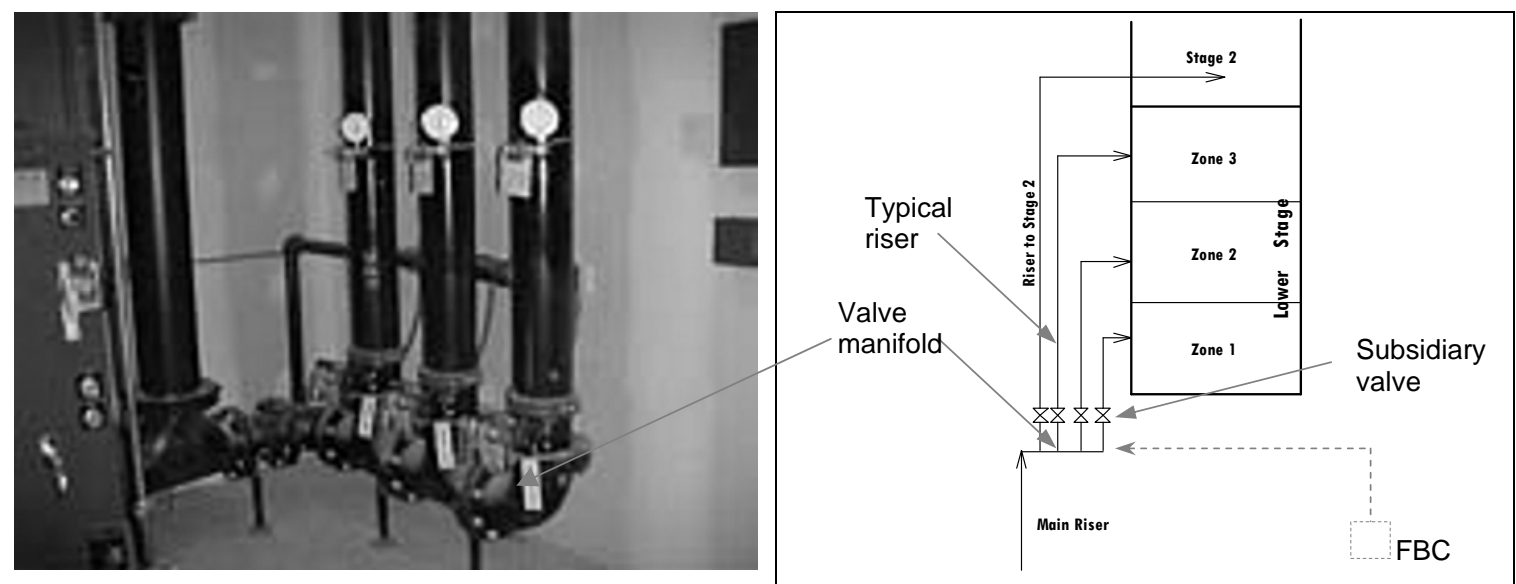

Fig. 3. Multiple risers supplying water (upward) to a high rise building (photograph from [8])

fault trees for an upfeed system where sprinkler does not deliver water at a location at zone 3 of stage 3 is presented in Fig. 4. The top event is selected as sprinkler does not deliver water at zone 3 of stage 3 (one of the most disadvantageous location of the building). That fault tree is expanded up to only six levels and further expansion can be viewed in [9].

Schematic diagram and a representative and shortened version of the fault tree for the downfeed system is presented in [6]. The top event is selected as sprinkler does not deliver water at zone 3 of lower stage which is the most disadvantageous locations of the building.

In the FTA, human actions that may result in a sprinkler system being inadequate for the hazard protected or create shielding have not been included. However, such actions can be included in an integrated system modeling.

\section{QUANTITATIVE EVALUATION/ SURVEY}

A survey has been conducted on the sprinkler systems in a number of Australian high-rise office buildings. Considerable effort was required to obtain the contact details of the building managers/ owners and to obtain their cooperation to carry out this survey. Once the building managers/ owners were contacted, the purpose of the study was explained and a questionnaire was sent out, in order for them to fully understand what was needed. Although the response was less than ideal, it was possible to get information from 23 different buildings out of nearly 60 buildings contacted. The identification details of these buildings are confidential and only the agglomerated data are presented below.

During the visit to the buildings, a standard questionnaire was used and the following documents were consulted (if made available):

- Asset registry

- Schematic diagram of the sprinkler system

- Records of sprinkler component repair/replacement works

- Records of informing fire brigade and insurer about sprinkler isolation of certain floors (system impairment) due to tenancy change etc.

- Records of periodic testing of sprinkler components

Unfortunately, not all of the above documents were kept for the entire life of many buildings, due to changes in management or older records had been archived, therefore some buildings only had records for the last two to five years. In one of the buildings, access was provided to the archive room and it was found very difficult to extract the relevant records from the chaotically archived documents.

Another limitation of this study is that poorly maintained buildings were generally not interested in taking part in the survey. It is also worth mentioning that the age of the surveyed building varied between 4 to 36 years. 


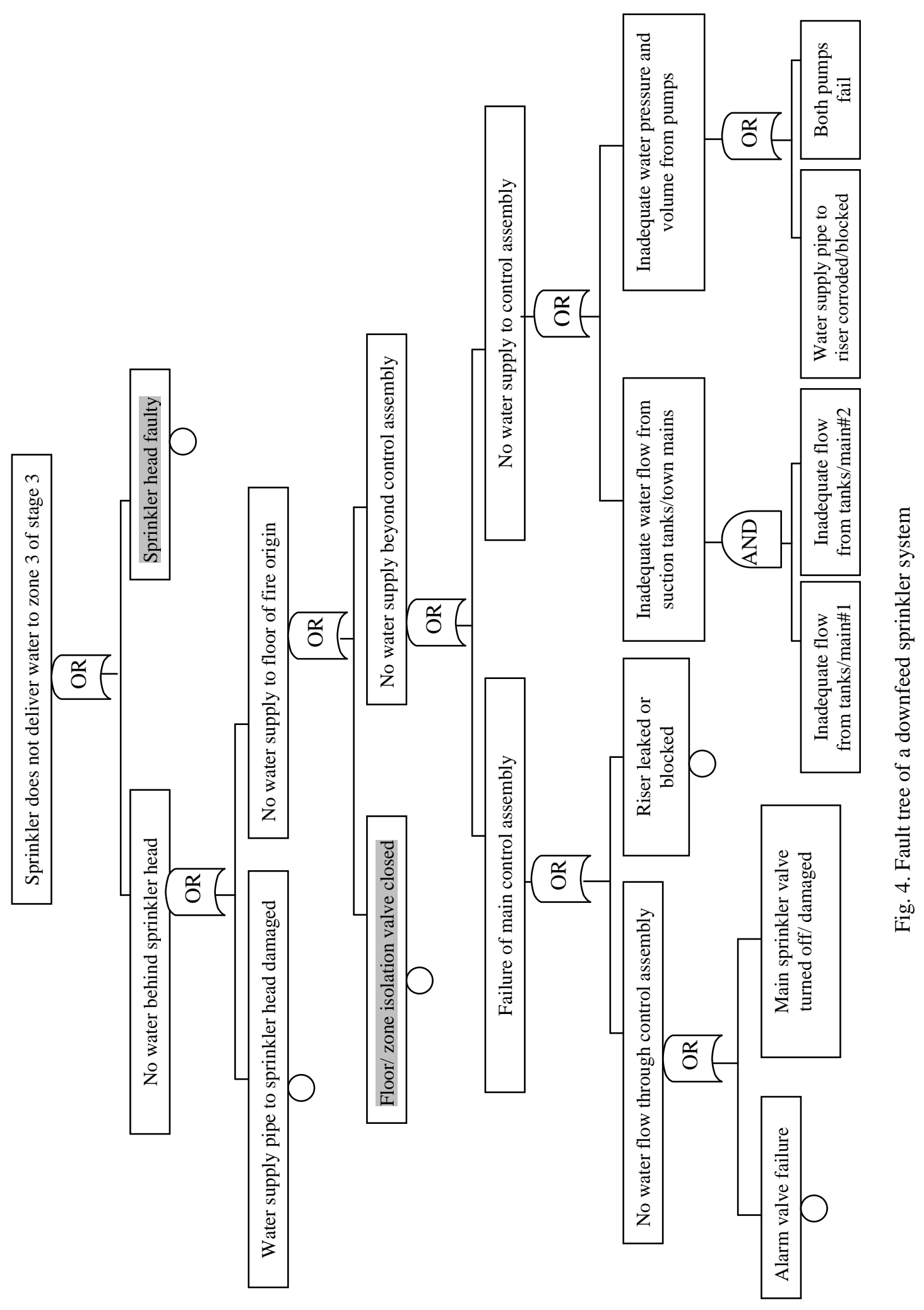


To calculate the top event frequency or probability, each basic event or undeveloped events need to be assigned a probability or frequency. The frequency of the relevant component failure frequency $\lambda$ (failure rate per unit time) of the system is computed using:

$$
\lambda=\frac{\text { total number of component failures }}{\text { total number of that component } \mathrm{x} \text { total period of data available (in years) }}
$$

The number of each component was either directly obtained from the asset registry or counted from the schematic diagram in order to find its failure rate per year.

If any component's failure frequency $(\lambda)$ and the interval between two successive maintenance visits $(t)$ are known, the probability of the failure or failure rate per demand $(\mathrm{P})$ can be found by [10]:

$$
\mathrm{P}=1-e^{-\lambda t}
$$

However, the time taken to repair or replace faulty components needs to be added to the interval between two successive maintenance to compute $t$. Therefore, during the survey, building facilities/ fire service mangers were asked the time typically taken to repair or replace faulty components.

\section{RESULT AND DISCUSSION}

\section{Failure statistics}

Failure rate per demand figure for each component has been computed from 23 buildings. It is important to see whether the number of surveyed buildings is sufficient to determine the reliability of all components of the sprinkler system. Therefore the mean value $(\mu)$ and standard deviation $(\sigma)$ data for each component is calculated as the survey is progressed. Once the values are plotted against the number of buildings surveyed, if the value does not significantly change with more buildings surveyed it can be considered that no more buildings are required to be included in the study.

In Fig. 5, the mean value data for each component is presented as the survey is progressed. The data is presented in semi-logarithmic scale. For most of the components after 10 buildings clear trends had emerged. By 20 buildings all profiles, except a very few, are quite stable.

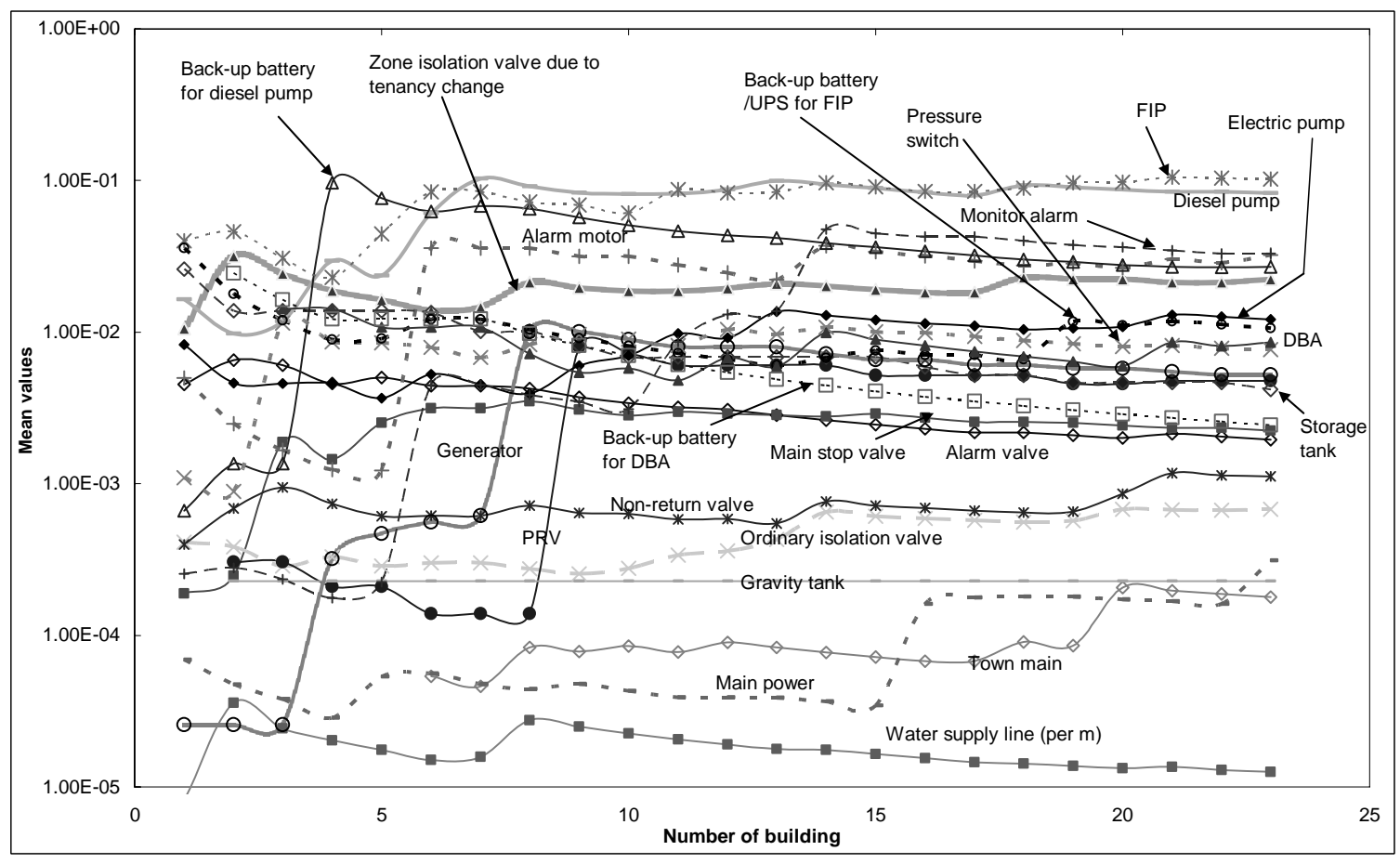

Fig. 5. Mean value data for each component against the number of building surveyed 
Similarly in Fig. 6, the standard deviation data for each component is presented as the survey is progressed in semi-logarithmic scale. Again by 20 buildings except for a few the standard deviation profiles are quite stable. Figures 5 and 6 demonstrate that the number of surveyed buildings is sufficient to determine the reliability of all components of the sprinkler system quite accurately.

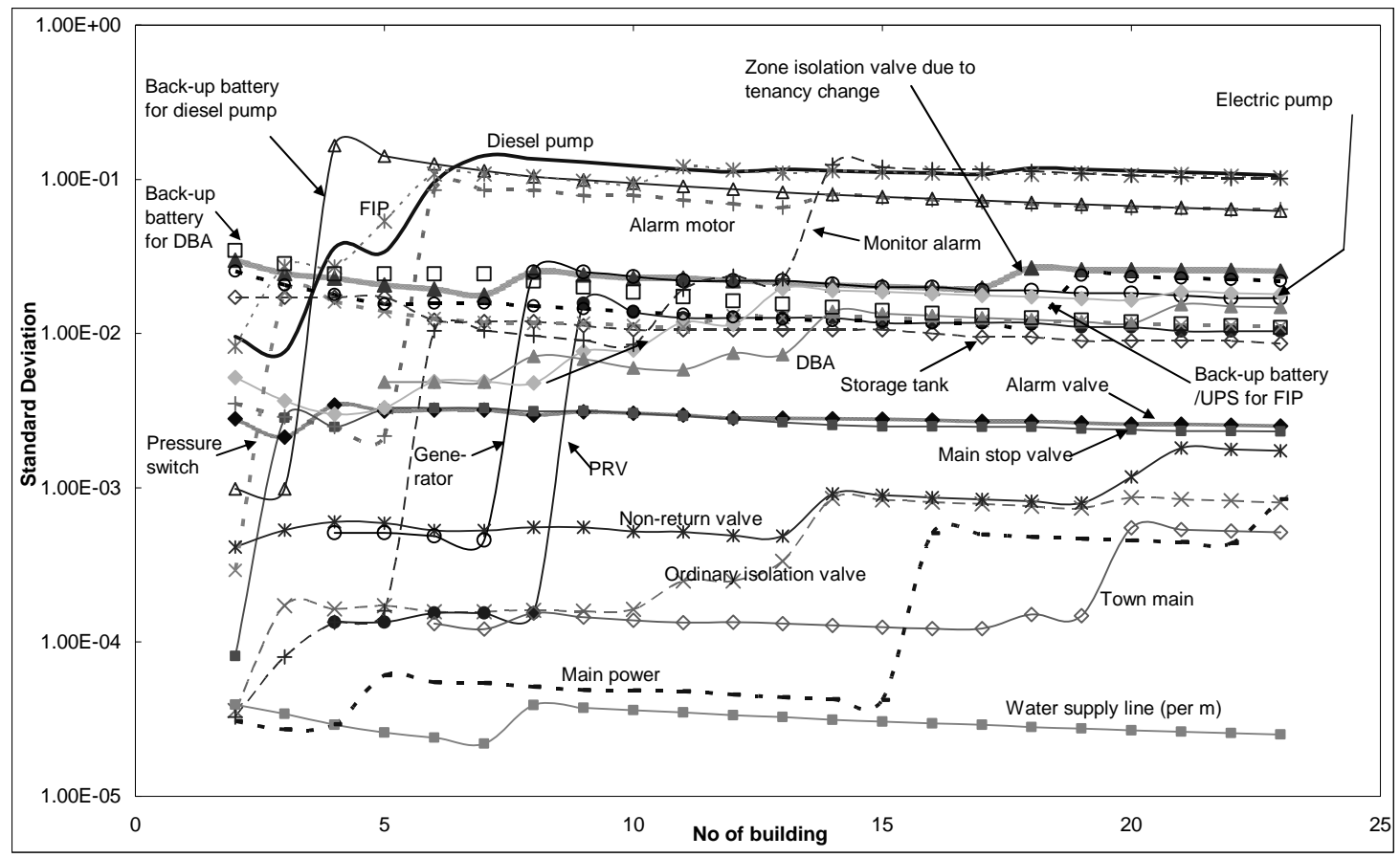

Fig. 6. Standard deviation data for each component against the number of building surveyed

To determine the upper limit of confidence interval (95\%) a rigorous analysis is required to determine the distribution pattern of each component data set. However, a simplified approach is presented in this paper where it is assumed that all data sets are likely to follow the normal distribution. 95\% confidence level $\left(P_{0.95}\right)$ can be calculated as:

$$
P_{0.95} \leq \mu+\frac{1.65 \sigma}{\sqrt{n}}
$$

In Equation (4), the term $\sqrt{n}$ is used, as the data represents the probability rather than some absolute value. Here $n$ represents the number of buildings from which pertinent data is collected.

The results of mean and $P_{0.95}$ failure probability of each component are tabulated in Table 1 . The figures for the same components from literature are also presented. The vertical axis is in logarithmic scale and the numbers are shown in inverse order i.e. the longer the column the lower its failure probability. Out of 22 components, 13 components data are found to be within the same order of magnitude of the data found in the literature. The remaining 9 components' failure probabilities are found to be higher than in the literature.

Using sensitivity analysis of the fault tree it is apparent that the top event is very sensitive to the failure probability of the following components:

- Sprinkler head

- Alarm valve
- Non-return valve

- Zone isolation valve
- Pressure switch

- Gravity tanks
- Pressure reducing valve

However, both survey and literature data reveal that the failure probability of these components is very small except for the sprinkler head and zone isolation valve (sprinkler downtime due to work during tenancy change). These two most important issues will be now discussed in detail. However, if the strict maintenance regulation and practice are not continued, the failure probability of other components is likely to rise significantly. 
Table 1. Failure Rate per demand of system components from the literature (References 17-35 of [9]) and the current study

\begin{tabular}{|c|c|c|c|c|}
\hline \multirow{2}{*}{ Component } & \multirow{2}{*}{ Literature data } & \multicolumn{3}{|c|}{ Current study } \\
\hline & & Mean value & 95\% confidence & $n$ \\
\hline Alarm valve & $1 \times 10^{-4}[23]$ & $20.3 \times 10^{-4}$ & $29.4 \times 10^{-4}$ & 21 \\
\hline Main stop valve & $\begin{array}{l}\text { 5.48, } 54.8,548 \times 10^{-3}[19],(1) \\
0.1 \times 10^{-3}[23]\end{array}$ & $2.33 \times 10^{-3}$ & $3.19 \times 10^{-3}$ & 20 \\
\hline $\begin{array}{l}\text { Zone isolation valve due to } \\
\text { tenancy changes }\end{array}$ & $4.0 \times 10^{-2}[18],(2)$ & $2.24 \times 10^{-2}$ & $3.17 \times 10^{-2}$ & 21 \\
\hline Ordinary Stop valve & $\begin{array}{c}5.48,54.8,548 \times 10^{-3}[19] \\
0.1 \times 10^{-3}[23]\end{array}$ & $0.67 \times 10^{-3}$ & $0.96 \times 10^{-3}$ & 22 \\
\hline Non-return valve & $\begin{array}{c}0.3,1.0,3.0 \times 10^{-4}[19] \\
0.1 \times 10^{-4} \quad[23]\end{array}$ & $11.3 \times 10^{-4}$ & $17.6 \times 10^{-4}$ & 22 \\
\hline Alarm gong & $2.68,3.62,4.81 \times 10^{-2}[19]$ & $2.56 \times 10^{-2}$ & $4.78 \times 10^{-2}$ & 21 \\
\hline Sprinkler head & $\begin{array}{c}420 \times 10^{-4}[17] \\
0.01 \times 10^{-4} \quad[18],[19]\end{array}$ & $782 \times 10^{-4}$ & - & - \\
\hline Town main & $1.5 \times 10^{-4}[18]$ & $1.87 \times 10^{-4}$ & $3.72 \times 10^{-4}$ & 22 \\
\hline Gravity tank & $\begin{array}{c}2.28 \times 10^{-4[18]} \\
+3.64 \times 10^{-4[28]}\end{array}$ & $2.28 \times 10^{-4}$ & $2.28 \times 10^{-4}$ & 9 \\
\hline Storage tank & $\begin{array}{c}2.28 \times 10^{-4[18]} \\
+3.64 \times 10^{-4[28]}\end{array}$ & $4.64 \times 10^{-3}$ & $9.34 \times 10^{-3}$ & 10 \\
\hline Water supply line (per m) & $2.6 \times 10^{-6[29]}$ & $12.9 \times 10^{-6}$ & $21.8 \times 10^{-6}$ & 23 \\
\hline $\begin{array}{l}\text { Back-up batteries for the } \\
\text { diesel pump }\end{array}$ & $8.0 \times 10^{-4}[18]$ & $268 \times 10^{-4}$ & $492 \times 10^{-4}$ & 22 \\
\hline $\begin{array}{l}\text { Back-up batteries/UPS for FIP } \\
\text { panel }\end{array}$ & $1 \times 10^{-3}$ & $9.99 \times 10^{-3}$ & $18 \times 10^{-3}$ & 21 \\
\hline Mains power in building & $5.0 \times 10^{-5[18]}$ & $16.1 \times 10^{-5}$ & $31.1 \times 10^{-5}$ & 23 \\
\hline Building power generator & & $5.24 \times 10^{-3}$ & $12.5 \times 10^{-3}$ & 15 \\
\hline Pressure switch & $\begin{array}{l}10 \times 10^{-4}[18] \\
1.0 \times 10^{-4}\end{array}$ & $78.2 \times 10^{-4}$ & $117 \times 10^{-4}$ & 23 \\
\hline Diesel pump & $3 \times 10^{-3}$ & $84.1 \times 10^{-3}$ & $121 \times 10^{-3}$ & 23 \\
\hline Electric pump & $0.3 \times 10^{-3}$ & $12.7 \times 10^{-3}$ & $19 \times 10^{-3}$ & 23 \\
\hline Direct brigade alarm & $1 \times 10^{-4}$ & $52.7 \times 10^{-4}$ & $95.7 \times 10^{-4}$ & 18 \\
\hline Jacking pump & & $9.85 \times 10^{-3}$ & $15.5 \times 10^{-3}$ & 12 \\
\hline $\begin{array}{l}\text { Back-up batteries for brigade } \\
\text { alarm }\end{array}$ & & $2.57 \times 10^{-3}$ & $6.71 \times 10^{-3}$ & 20 \\
\hline Pressure reducing valve & $\begin{array}{l}0.05 \times 10^{-3} \\
10 \times 10^{-3} \quad[25],[27] \\
4.37 \times 10^{-3}\end{array}$ & $4.77 \times 10^{-3}$ & $10.4 \times 10^{-3}$ & 9 \\
\hline FIP & $6.43 \times 10^{-2}$ & $9.9 \times 10^{-2}$ & $13.5 \times 10^{-2}$ & 21 \\
\hline Back-up batteries/UPS for FIP & $3.13 \times 10^{-2}$ & $1.0 \times 10^{-2}$ & $1.80 \times 10^{-2}$ & 21 \\
\hline Monitor alarm/sensor & $7.76 \times 10^{-2}$ & $3.29 \times 10^{-2}$ & $7.02 \times 10^{-2}$ & 20 \\
\hline $\begin{array}{l}\text { Fail to observe monitor alarm } \\
\text { activation }\end{array}$ & $3.0 \times 10^{-2}$ & Cou & lot be determined & \\
\hline $\begin{array}{l}\text { Underground pipe from town } \\
\text { mains to tank corroded }\end{array}$ & $1.0 \times 10^{-4}$ & Cou & ot be determined & \\
\hline
\end{tabular}

(1) When 3 figures are presented they represent $P_{0.05}, \mu$ and $P_{0.95}$ respectively

(2) Based on 15 tenancy changes in a 37 storey building in a year. Eight floors are connected by one subsidiary valve. During a tenancy change, this valve is shut for 4.05 days. 


\section{Sprinkler downtime due to work during tenancy change}

In most buildings the only means of interrupting the water flow to a floor during a tenancy change is to turn off the sprinkler valve on the riser. Figure 2 shows that eight floors are connected by one zone isolation valve. Therefore, all connected floors are not supplied with sprinkler water for a number of days. However, it has been found from the survey that during the tenancy changes, sprinkler valves are only usually shut during the daytime. In some buildings, sprinkler valve isolation was restricted to during weekends only. The buildings have the policies of restriction on sprinkler isolation time, which varies from 8 to 10 hours a day.

The probability that sprinkler valve is turned off, $\mathrm{P}(\mathrm{V})$, can be calculated as:

$$
\mathrm{P}(\mathrm{V})=\frac{\text { no of changes per } \mathrm{yr} \times \text { no of days per change } \times \text { no of isolation hrs per day } \times \text { no of fls connected to a valve }}{\text { total no of fls in the building } \times \text { no of days per yr } \times \text { no of hrs per day }}
$$

It has also been found that the building facility/ fire service mangers are aware of the dangers during a tenancy change period. The danger during this period is exacerbated by the fact that hot-working is often also carried out at the same time in the unprotected area. In many buildings for such periods, physical patrolling is arranged. Applying Equation (3) to surveyed building data, mean $\mathrm{P}(\mathrm{V})$ is found to be 0.0224 which is significantly lower than the value found in [11] which may be attributed to not allowing sprinkler isolation during night time. Thomas et al [11] found that sprinkler valve shut off during tenancy changes was the main factor that may lead to a sprinkler system failure. It was also shown by Bugbee [12] from US fire data between 1925-1969 that sprinkler shut off accounts for 35.4\% of the sprinkler system failure (the next highest proportion of the cause was just 13.5\%).

\section{Sprinkler Head Reliability}

\section{Previous study}

Nash and Young [13] present some data of sprinkler head testing from 1960-1970 in the UK, where 1967 new as well as 175 old heads were tested. For new heads, a probability of 0.009 was observed for complete blockage, 0.023 for partial blockage, thus a total failure probability of 0.032 . For old heads, the respective figures were $0.017,0.034$ and 0.051 .

Watanbe [14] developed a fault tree of sprinkler system based on the 100 Japanese fire reports by welltrained investigators. He found that the failure probability of sprinkler heads is 0.0028 . It should be noted that this is not the failure probability for a single sprinkler head, rather the combined failure of one or more heads located in the vicinity of a fire.

Zhuiykov and Dowling [15] presented the test data of 6350 sprinkler heads conducted in Australia in the time interval of 1992-2005. Of those sprinkler heads 500 failed (outside specification) resulting in a failure probability of 0.079 which is within the same order of magnitude as obtained from above [13]. The Australian Standard AS 1851.3 [16] requires testing of representative samples of sprinklers in a system after 24 years in service, and then at six-year intervals thereafter. It appears that most of these tested heads are at least 24 years old. Furthermore, these tested heads are not only from the office buildings rather from all types of occupancies. Many of these had apparently been installed and maintained in abnormal environments, such as corrosion, abnormally high temperatures or mechanical abuse compared to office environments.

\section{Current study}

In the current study, sprinkler head testing data was found only from two buildings. The result is tabulated in Table 2:

Table 2. Failure Rate per demand for sprinkler heads from the current study

\begin{tabular}{|c|c|c|c|c|}
\hline $\begin{array}{l}\text { Building } \\
\text { No }\end{array}$ & $\begin{array}{c}\text { No of head } \\
\text { tested }\end{array}$ & $\begin{array}{l}\text { No of head outside } \\
\text { specification }\end{array}$ & $\begin{array}{c}\text { No of head } \\
\text { critically failed }\end{array}$ & Critical failure probability \\
\hline 1 & 20 & 12 & 6 & 0.3 \\
\hline 2 & 100 & 2 & 0 & 0.0 \\
\hline
\end{tabular}

${ }^{1}$ did not go off even at $90^{\circ} \mathrm{C}$ temperature while the nominal operating temperature was $68^{\circ} \mathrm{C}$. 
A critical failure probability of 0.3 for Building 1 heads is extremely high compare to the other study. However, the critically failed sprinkler heads were tested until the temperature of $90^{\circ} \mathrm{C}$ and the tests discontinued if the heads were not activated. There is a likelihood that those heads could be activated at a temperature higher than $90^{\circ} \mathrm{C}$ and in the event of a fire those late activated heads (though not ideal) would play some role in controlling the fire. During one of the sprinklered office fire tests of Proe and Bennetts [17] due to inadvertent closing of the supply, water was delivered through a single sprinkler head 2 minutes after sprinkler activation. Although the fire got bigger, that single head had no trouble in controlling the fire.

\section{Discussion}

It is clear that a popular perception of high sprinkler reliability i.e. a failure probability of $1 \mathrm{E}-06$ is not supported. The popular perception may be correct at the time of manufacturing, but clearly not after few years of installation and use. Based on the above data the failure probability of a single head is taken as 0.079 from [12] as the data from the study is Australian and conservative in a sense that many of the tested heads were subject to extreme conditions compared to the office environment.

However, failure of a single sprinkler head does not necessarily reflect failure of the sprinkler system. If the head nearest to the fire fails, the adjacent heads are likely to be activated and can suppress the fire. On the other hand, adjacent sprinkler heads are likely to be from the same batch. Therefore, there is a strong possibility that if one head fails the adjacent heads will fail too.

For the purpose of this paper, it considered that to represent the combined failure of sprinkler heads located in the vicinity of a fire at least two sprinkler heads need to be failed. Therefore the combined failure of two sprinkler heads is considered as $0.079 \times 0.079=0.0062$. However, cases are also considered where a single head failure may represent the combined failure of sprinkler heads located in the vicinity of a fire.

\section{Sprinkler system reliability}

It is important to mention that some buildings draw sprinkler water from only one town main and some of the buildings (usually $<20$ storey) do not have power generator to back up the street power supply. This FTA is conducted for a 60 storey office building which draws sprinkler water from two independent town mains and has power generator to back up street power supply.

From FTA the failure probability of sprinkler system for different systems, for the most disadvantageous zones, are shown in Table 3. In all cases two situations are considered:

- 2 head: for combined failure of sprinkler heads at least 2 heads need to be failed.

- 1 head: for combined failure of sprinkler heads 1 head failure is sufficient.

Table 3. Failure probability of sprinkler system

\begin{tabular}{|c|c|c|c|c|}
\hline \multirow{2}{*}{ Type of System } & \multicolumn{2}{|c|}{ Based on mean value } & \multicolumn{2}{|c|}{ Based on $\boldsymbol{P}_{\mathbf{0 . 9 5}}$} \\
\cline { 2 - 5 } & $\mathbf{2}$ head & $\mathbf{1}$ head & 2 head & 1 head \\
\hline $\begin{array}{c}\text { upfeed } \\
\text { (with no basement tank) }\end{array}$ & $4.6 \%$ & $11.5 \%{ }^{1}$ & $6.9 \%$ & $13.7 \%$ \\
\hline downfeed & $3.0 \%$ & $10.0 \%$ & $4.0 \%$ & $10.9 \%$ \\
\hline
\end{tabular}

${ }^{1}$ This was estimated as $4.45 \%$ by [11].

It can be observed that based on current survey data, the failure probability of the sprinkler system in Australian high-rise building lies in between $3 \%$ to $14 \%$ which is higher than the commonly considered values of 5\% (non-flashover fire) and 1\% (flashover fire) [15]. However, the failure probability figure from FTA could not be compared with the one from fire statistics as sufficient Australian data is not available.

Once the data for five buildings were processed the failure probability of the sprinkler system was computed. The failure probability is calculated as more buildings are surveyed. In Fig. 7 the failure probability figure, based on the mean value of each component and consideration of at least 2 sprinkler heads need to be failed, is presented as the survey is progressed. By 20 buildings both profiles are found to be quite stable reflecting that statistically sufficient number of buildings have been surveyed. 


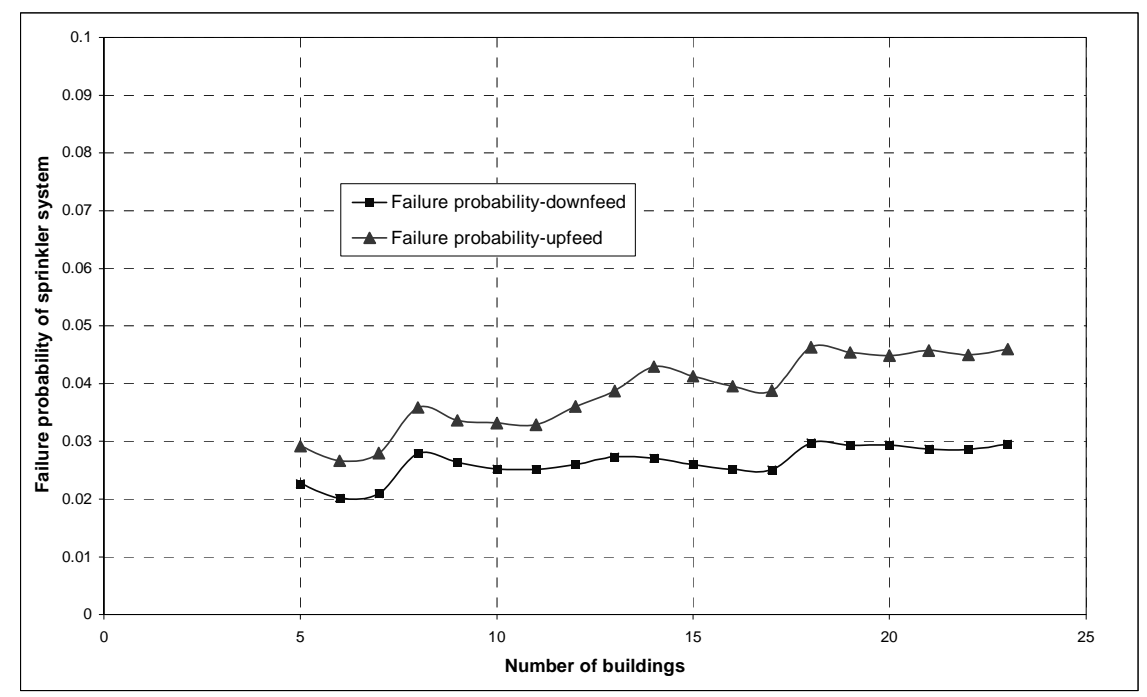

Fig. 7. Failure probability data for sprinkler systems against the number of building surveyed

\section{RECOMMENDATION FOR IMPROVEMENTS}

It is found in this study that sprinkler system failure can be mainly attributed to sprinkler downtime due to work during tenancy change and the sprinkler head failure. Sprinkler downtime can be reduced by the following means:

- Installing sprinkler isolation valve for each floor. If all the surveyed buildings were installed with isolation valve for each floor, the failure probability would be as per Table 4 .

Table 4 Failure probability of sprinkler system when valves are installed for each floor

\begin{tabular}{|c|c|c|c|c|}
\hline \multirow{2}{*}{ Type of System } & \multicolumn{2}{|c|}{ Based on mean value } & \multicolumn{2}{c|}{ Based on $\boldsymbol{P}_{0.95}$} \\
\cline { 2 - 5 } & $\mathbf{2}$ head & $\mathbf{1}$ head & 2 head & 1 head \\
\hline $\begin{array}{c}\text { upfeed } \\
\text { (with no basement tank) }\end{array}$ & $3.0 \%$ & $10.0 \%$ & $4.5 \%$ & $11.4 \%$ \\
\hline downfeed & $1.3 \%$ & $8.4 \%$ & $1.5 \%$ & $8.7 \%$ \\
\hline
\end{tabular}

It can be observed that the failure probability of the same sprinkler system can be reduced between 0.015 to 0.025 which amounts to an improvement in the range of $13-62 \%$ by this measure.

- Use of flexible sprinkler pipes connecting the riser and the sprinkler head. This will result in relocating sprinkler heads without isolating the sprinkler system for minor rearrangement of the office. However, the reliability of a flexible pipe compared to a rigid pipe is not known. Therefore, it is not yet clear whether such a measure will reduce the overall failure probability of the system.

The initial testing interval of representative samples of fast-response sprinklers heads (required for office buildings) is now reduced to 12 years, then at 12 years and then at six-year intervals thereafter as per Australian Standard AS 1851-2005 [19]. This will likely to reduce the sprinkler head failure probability.

\section{CONCLUSIONS}

The use of a physical survey is an effective means of gathering detailed information on the reliability of sprinkler system. Although it was challenging to involve the building owners in the study, it was possible to come up with some data by consulting relevant documents. Whether there were records kept of the entire life of the building or only up to two years, these documents allowed calculation of the failure probability of various components of sprinkler system. In the process, time taken to repair or replace faulty components has been incorporated.

The results show that out of 22 components, 13 components of the data are found to be within the same order of magnitude of the data found in the literature. The remaining 9 components' failure probabilities are found to be much higher than the literature data. 
The reliability of the sprinkler system is estimated based on number of considerations. It can be observed that the failure probability of the sprinkler system in a 60 storey Australian office building lies in the range $3 \%$ to $14 \%$ which is higher than the commonly considered values in Australia.

Sprinkler zone shut off during tenancy changes and sprinkler heads appear to be the main factors that may lead to a sprinkler system failure. In spite of the improvement in reliability with respect to the sprinkler zone shut off during tenancy changes, it remains one of the main causes leading to a sprinkler system failure. In regard to this, by installing zone isolation valve for each floor, the failure probability of a sprinkler system can be reduced between $13 \%$ to $62 \%$.

\section{REFERENCES}

[1] International Fire Service Training Association, Essentials of Fire Fighting, 4th Ed, ISBN 087939-149-9, 1998.

[2] Thomas, I. R., "Effectiveness of Fire Safety Components and Systems", Proceeding of the International Conference on Engineered Fire Protection Design, 2001, pp151 - 173.

[3] Kim, W.K., Exterior Fire Propagation in a High Rise Building, Masters Thesis, Worcester Polytechnic Institute, USA, 1990.

[4] Rohr, K. D. and Hall Jr., J. R., "U.S. Experience with Sprinklers and Other Fire Extinguishing Equipmen” NFPA Fire Analysis and Research, Quincy, MA, USA, August 2005.

[5] Standard Australia, Sprinklers Simplified, ISBN 0-7337-3037-X, 2000.

[6] Moinuddin, K. A. M., Thomas, I. R, Chea, S. and Bennetts, I. D. "Factors Affecting the Reliability of Sprinkler System in Australian High Rise Office Buildings" Proceeding of 7th Asia-Oceania Symposium on Fire Science \& Technology, 2007, Hong Kong.

[7] Australian StandardTM, “Automatic Fire Sprinkler Systems”, AS2118.1-1999, 1999.

[8] Piccolo, R. "Back to Basics: Sprinkler Design for Multi-Tenant Buildings” PM Engineer, 2004.

[9] Moinuddin, K. A. M., Bennetts, I. D. Thomas, I. R. and S. Chea, "An Assessment of Sprinkler System Reliability In High Rise Commercial Buildings”, Victoria University Internal Report (Draft), 2007.

[10] Beck V. "Fire code Reform Centre Project 4, Fire Safety Design Solutions Part 1: Core Model and Residential Buildings Project Specifications”, Victoria University Internal Report 1995.

[11] Thomas, I. R., Bennetts, I. D., Poon, S. L. and Sims, J. A. "The Effect of Fire in the Building at 140 William Street”, BHP Research Report BHPR/ENG/R/ 92/044/SG2C, February 1992

[12] Bugbee, P. 1978, Principles of Fire Protection ISBN 0877653453.

[13] Nash, P. \& Young, R.A. 1991. Automatic Sprinkler Systems for Fire Protection, 2nd Ed. Paramount Publishing, Borehamwood, 1991.

[14] Watanabe, A. 1979. "Effectiveness of Active Fire Protection Systems". In: U.S./Japan Government Cooperative Program on Natural Resources (UJNR). Fire Research and Safety. 4th Joint Panel Meeting. February 5-9, 1979, Tokyo, Japan, 1979, s. 22-37.

[15] Zhuiykov, S. and Dowling, V. "Maintenance Testing of Sprinkler Heads: Qualitative Analysis Causes of Failures" Fire Safety Science -- Proceedings of the Eighth Int. Symp., International Association for Fire Safety Science, 2005, pp. 811-822. doi:10.3801/IAFSS.FSS.8-811

[16] Australian Standard "Maintenance of Fire Protection Equipment - Automatic Fire Sprinkler Systems,”AS 1851.3-1997, 1997.

[17] Proe, D. J. and Bennetts, I. D. "Six Fire Tests in a Large Sprinkler-Protected Open-Plan Office", BHP Research Report No: BHPR/SM/R/92/010, May 1997.

[18] Fire Code Reform Centre, Fire Engineering Guidelines, 1st Ed., Sydney, Australia, March 1996.

[19] Australian Standard"M “Maintenance of Fire Protection Systems and Equipment,”AS 1851-2005, 2005. 